\title{
Factors Affecting Enterprise's Satisfaction toward Social Security's Online Public Service: The Case of Thanh Hoa Province, Vietnam
}

\author{
Chi Thanh NGO ${ }^{1}$, Thi Ngoc Mai NGUYEN² , Duy Dat NGUYEN ${ }^{3}$, Hoang Ba Huyen LE \\ Van Cuong LE ${ }^{5}$, Thi Binh LE ${ }^{6}$
}

Received: June 26, 2020 Revised: July 12, 2020 Accepted: August 10, 2020

\begin{abstract}
The study aims to investigate factors affecting enterprise's satisfaction and loyalty toward the Social Security's online public services, looking at the case of Thanh Hoa province, Vietnam. This study employs samples with 216 enterprises that use online public system of Thanh Hoa province's Social Security. The research model is closely linked to the SERVQUAL model developed by Parasuraman, Zeithaml and Berry (1988). We propose 23 scales that constitute the quality of service, three scales that constitute Customer Satisfaction and three components that constitute Customer Loyalty. This study use the tool of Exploratory Factor Analysis (EFA), Cronbach's Alpha test, Confirm Factor Analysis (CFA) and Structural Equation Modeling (SEM) in order to address the question of satisfaction and loyalty. The result shows that the factor with the most impact is Reliability, next is Capacity of staffs, Tangibles, Attitude of staffs, and the least impacting factor is Empathy; moreover, the results also show that Satisfaction has a strong impact on Customer Loyalty. The findings of this study suggest that Thanh Hoa province's Social Security should: (i) strengthen the reliability of online service system; (ii) build capacity for staffs; (iii) develop the responsiveness of electronic transactions systems; and (iv) improve the empathy of staffs.
\end{abstract}

Keywords: Online Service System, Social Security, Satisfaction, Loyalty, Thanh Hoa Province, Vietnam

JEL Classification Code: M21, M31, M37, D7, C5

\section{Introduction}

${ }^{1}$ First Author and Corresponding Author. Lecturer, Faculty of Economics and Business Administration, Technology and Science Management Department, Hong Duc University, Vietnam [Postal Address: No 565, Quang Trung, Dong Ve Ward, Thanh Hoa City, Thanh Hoa Province, 40000-42000, Vietnam]

Email: ngochithanh@hdu.edu.vn

${ }^{2}$ Department of Organization and Personnel, Social Security Office, Thanh Hoa Province, Vietnam. Email: ngocmai0302@gmail.com

${ }^{3}$ Lecturer, Faculty of International Business and Economics,

THUONGMAI University, Ha Noi, Vietnam.

Email: Dat.nd@tmu.edu.vn

${ }^{4}$ Lecturer, Faculty of Economics and Business Administration, Hong

Duc University, Vietnam. Email: lehoangbahuyen@hdu.edu.vn

${ }^{5}$ Lecturer, Faculty of Economics and Business Administration, Hong

Duc University, Vietnam. Email: levancuong@hdu.edu.vn

${ }^{6}$ Lecturer, Faculty of Economics and Business Administration, Hong

Duc University, Vietnam. Email: lethibinhkt@hdu.edu.vn

(c) Copyright: The Author(s)

This is an Open Access article distributed under the terms of the Creative Commons Attribution Non-Commercial License (https://creativecommons.org/licenses/by-nc/4.0/) which permits unrestricted non-commercial use, distribution, and reproduction in any medium, provided the original work is properly cited.
Public services in general and online public services in particular are of considerable interest to several governments (Rhee \& Rha, 2009; Van de Wall \& Scott, 2009; Fan \& Yang, 2015). In Vietnam, the Government has issued several regulations on implementation and development of online public services (see Decree No. 43/2011/NĐ-CP, date: June/13/2011; Decree: 45/2020/NĐ-CP, date:April/04/2020). Based on such basis, the usage of online public services has made significant progress in recent years. For instance, in the case of Thanh Hoa province, from September 2019 up to March 2020, level 3 online public services activities have received a total of 16,500 dossiers registered by the administrative centers to process, accounting for $6.53 \%$ of the total, compared with the requirements. Level 4 online public services have received a total of 2,879 records to be processed by the administrative centers, accounting for $42.03 \%$ of total (exceeding the set target).

In recent years, Vietnam Social Security has implemented online public services through the application of information technology and networking; conducting electronic transactions for procedures of declaration, collection, 
remittance and settlement of policies of social insurance, health insurance and unemployment insurance in several activities included managing revenue, payment, receiving dossiers, and returning administrative procedure results. This online public service in fact contributes to administrative reform in the field of social insurance, and improves the efficiency of social insurance agencies.

To perform publicity and transparency of administrative procedures, Thanh Hoa Social Security Office has deployed organizations and individuals to register and use electronic transactions when participating in social security activities. According to the statistics of Thanh Hoa Social Security Office, in 2015, 2,562 units participated in electronic transactions; by 2018 , the number increased rapidly to 8,784 units (accounting for $97.6 \%$ of units participating in social security) registered for using in payment of social security.

Although Thanh Hoa Social Security Office has obtained positive results from online public service, this activity also faced numerous challenges in order to improve the customer's satisfaction, in particularly, to satisfy the enterprises with numerous employees enrolled in social security. From that state of affairs, this article studies the factors affecting enterprises' satisfaction with the online public services at the Social Security Office of Thanh Hoa province.

\section{Literature Review}

The issue of service quality and the link with the satisfaction of customers are studied by several scholars. Lehtinen and Lehtinen (1982) state that service quality should be evaluated in two aspects: (i) processing of service offering and (ii) the result of services. Gröngoos (1984) mentions that service quality is measured by comparing the value, which customers expected before using services, with the value obtaining after using services. Koller and Keller (2007) show that products or service have quality when they satisfy customers over their expectations. In another aspect, service and satisfaction have a relationship with each other, where service quality and satisfaction are linked together toward the higher service quality, leading to the higher customer satisfaction. Therefore, service quality should go together with the satisfaction of customers (Cronin \& Taylor, 1992; Koller \& Keller, 2007). In order to measure service quality, Parasuraman, Zeithaml and Berry (1988) propose the SERVQUAL model with five main factors: (1) Tangibles; (2) Reliability; (3) Responsiveness; (4) Assurance; (5) Empathy, while Zeithaml (2000) emphasizes that price, situation, and personal characteristics are factors directly influencing the satisfaction of customers.

The issue of factors affecting the satisfaction of customers using online services in general (including E-Commerce) and public online service in particular is present in the literature.
For instance, in the case of Vietnam, this topic is treated at different levels and aspects: at the town level, Ngo (2016) analyzes People's Satisfaction toward Public Administrative Services at the People's Committee of Di An Town (Binh Duong province). The research emphasized that Facilities, Reliability, Staff Capacity, Service attitude, Empathy, and Procedures are important factors affecting the satisfaction of the people. At the district level, several research related to People's Satisfaction towards Public Administrative Services has been done, including Nguyen (2014) who studied for the case of Dak Ha District (Kon Tum province); at the province (or city) level, the reader can refer to the interesting research by Nguyen (2019) who analyzes the case of Tra Vinh Provincial Center which indicated that procedures, service fee, attitudes of the staff, empathy, staff capacity, and trust are crucial factors affecting the people's satisfaction toward Public Administrative Services. If we look for the case of the customer satisfaction for online service of enterprises, the new study by Giao (2020) analyzes factors that affect customer satisfaction of online service quality of Tiki.vn; other research on E- Commerce Trade includes He and Wang (2019) for a Panel Analysis on the Cross Border E-commerce Trade in ASEAN countries, or Kussusanti, Tjiptoherijanto, Halim and Furinto (2019) for a research on informational justice and post-recovery satisfaction in E-Commerce, which focuses on the role of service failure severity on behavioral intentions.

On the aspect of the link between satisfaction and loyalty of customer, Gremler and Brown (1996) argued that loyalty is the level at which a customer demonstrates a repeat behavior of the purchase of products and services; it also has a positive attitude toward the supplier and intends only to use these products (or services). There are several studies emphasizing the existence of a link between satisfaction and loyalty of customers. For instance, Zeithaml, Berry and Parasuramant (1996), Cronin and Taylor (1992), and Chen (2008) show the direct effect of satisfaction affects directly the same way it affects customer loyalty. The authors also state that, when customer satisfaction increases, customers will be willing to continue using products (or services) of a certain brand and will be willing to introduce others about that product (or service).

To our best knowledge, most of works in this field has focused on the satisfaction of customers toward public services, but not on public online service. Moreover, have not yet been addressed the question of the satisfaction of customers with public online service in the field of social insurance and the link with loyalty as well. From that point of view, the objective of this paper is to study the factors affecting the satisfaction and loyalty of customers toward online public services at Thanh Hoa province social insurance, Vietnam. 


\section{Research methodology}

\subsection{Research Model and Hypotheses}

In this study, we aim to evaluate the impact of the components of the quality of online public services at Social Security in Thanh Hoa province on customer satisfaction and loyalty. The author therefore chooses 23 scales that constitute the quality of service, three scales that constitute Customer Satisfaction and three components that constitute Customer Loyalty. Based on frameworks derived from the literature review of Thanh Hoa province's Social Insurance, the scale of service quality includes five factors: (i) Reliability, (ii) Tangibles, (iii) Capacity of staffs, (iv) Attitude of staffs, and (v) Empathy. Our model is mostly linked to the concept underlying the SERVQUAL model. The research model was established based on the assumptions that the components of service quality have a direct impact on satisfaction that directly affects loyalty of customer. Other factors such as procedures or service fee could be considered, however, due to the feature of online public service system, in particularly in the field of social insurance, the research should focus more on the factor of reliability, this factor also covers several parameters linked to procedures. From that point of view, the research model is presented in Figure 1.

Hypothesis:

H1: The reliability of online public services of Thanh Hoa province's Social Security has a positive relationship with customer satisfaction.

H2: The tangibles of online public services of Thanh Hoa province's Social Security have a positive relationship with the customer satisfaction.

H3: The capacity of staffs of online public services of Thanh Hoa province's Social Security has a positive relationship with the customer satisfaction.
H4: The attitude of staffs of online public services of Thanh Hoa province's Social Security has a positive relationship with the customer satisfaction.

H5: The empathy of online public services of Thanh Hoa province's Social Security has a positive relationship with the customer satisfaction.

H6: The customer satisfaction of online public services of Thanh Hoa province's Social Security has a positive impact on customer loyalty.

\subsection{Research Scale and Analysis Methodology}

The scale of customer satisfaction assessment for online public services at Thanh Hoa Social Security is built based on the studies presented in the literature review, then adjusted to link the context to Thanh Hoa Social Security through qualitative research by group discussion and expert consultation. After adjustment, the final scale is presented as: (i) Reliability (RE: RE1, RE2, RE3, RE4, RE5); (ii) Tangibles (TA: TA1, TA2, TA3, TA4); (iii) Capacity of staffs (CA: CA1, CA2, CA3, CA4, CA5); (iv) Attitude of staffs (AT: AT1, AT2, AT3, AT4, AT5); (v) Empathy (EM: EM1, EM2, EM3, EM4); (vi) Customer satisfaction (SA: SA1, SA2, SA3); (vii) Customer loyalty (LOY: LOY1, LOY2, LO3).

\subsection{Description of Data}

\subsubsection{Subjects of Study}

Research subjects are enterprises using online public services at Social Security in Thanh Hoa province. The non-probability sampling method was used, where sample subjects are selected based on the evaluation of scholars (Black, 2010). The scale used is a 5-point Likert scale with 1 being completely disagree and 5 is strongly agree.

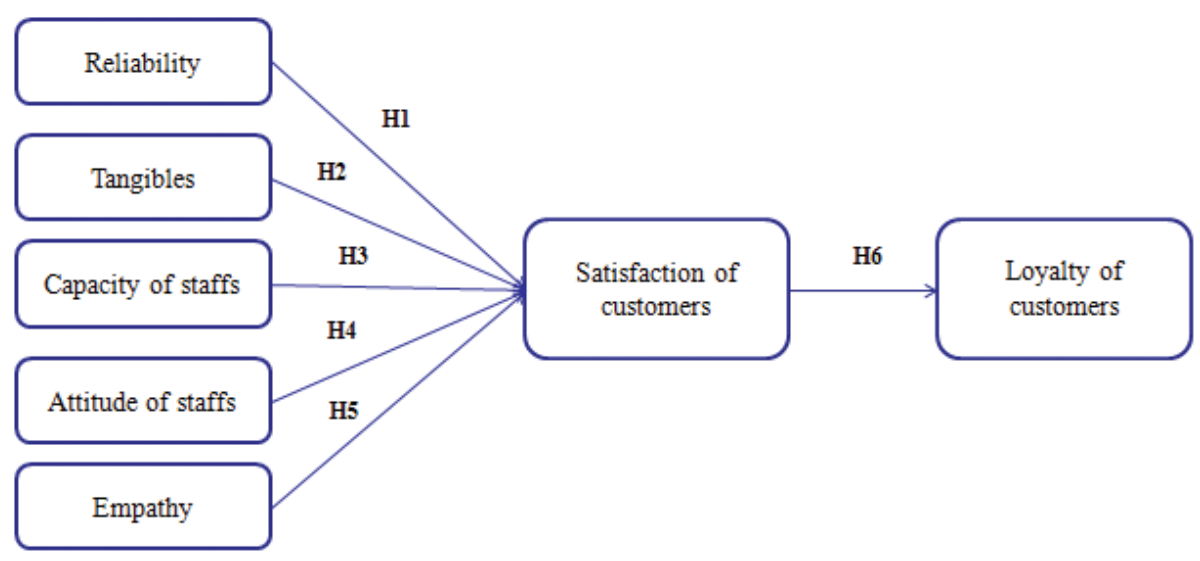

Figure 1: The research model 


\subsubsection{Scope of Study Sample}

Hair, Black, Babin, Anderson, and Tatham (1998) recommends that, if the sample size is around 100, the loading factor standard must be greater than 0.5 , while Bollen (1986) proposed the ratio of five observations per estimated parameter in the multivariate analysis. In the research, there are 29 variable observations, so the minimum sample size should be equal to $29 * 5=145$ samples. The study has a sample size of 230 enterprises that use online public system of Thanh Hoa province's Social Insurance, which can meet the requirements and be generalizable. The total number of valid questionnaires collected and processed was 216 questionnaires.

\subsubsection{Analytical Methods}

The research uses the following methods: exploratory factor analysis (EFA), confirmatory factor analysis (CFA), and structural equation model (SEM), with SPSS.22 software in combination with AMOS.22. Cronbach's Alpha testing is used to evaluate the reliability of the scale of variables, and to eliminate the inadequate variables. Exploratory factor analysis is for developing a scale and identifying an underlying relationship between measured variables. The confirmatory factor analysis is used to redefine univariate, multivariate, convergent and discriminant values of concepts. From the CFA results, structural equation analysis is used to construct and validate the relevance of the research model and also assess the impact level of independent variables on the dependent variable.

\subsection{Research Data}

In this study, we conduct a questionnaire survey with 216 enterprises that use online public system of Thanh Hoa province's Social Security. In order to ensure comprehensive research results, the survey samples were involving with all types of businesses, including: state-owned enterprises, private enterprises, and diversified business fields. More precisely, of 216 surveyed private enterprises $34,5 \%$ are private companies, $26 \%$ limited companies, $33,5 \%$ joint-stock companies, and the remaining is other types. Selecting this research sample is suitable with the context of Thanh Hoa province since most of these three types of enterprises are using online public services of Thanh Hoa province's Social Security. Of the 216 enterprises surveyed, the proportion of businesses operating in the commercial sector accounted for $33 \%$, while manufacturing the sector accounted for $32 \%$ and the service sector accounted for $28.5 \%$. As regards the number of employees, $87 \%$ of surveyed enterprises have from 50 to less than 150 employees, which is reflected by the fact that most companies in Thanh Hoa province are small- and medium-sized enterprises (SME). The selection of companies by business sectors and number of employees is suitable in the context of Thanh Hoa province in order to reflect the satisfaction of customers towards online public service system. The details of the research data are presented in Table 1.

Table 1: Descriptive statistics of the sampling

\begin{tabular}{|c|l|c|c|}
\hline No & lontend & Number (people) & Proportion (\%) \\
\hline & Number of people surveyed & 216 & 100 \\
\hline & Type of companies & 74 & 34.5 \\
\hline 1 & Private companies & 56 & 26 \\
\hline 2 & Limited companies & 72 & 33.5 \\
\hline 3 & Joint stock companies & 14 & 6.0 \\
\hline 4 & Other types & \multicolumn{2}{|l|}{} \\
\hline & Business sectors & 69 & 32 \\
\hline 1 & Production & 71 & 33 \\
\hline 2 & Commercial & 62 & 28.5 \\
\hline 3 & Service & 14 & 6.5 \\
\hline 4 & Other sectors & 7 & 3 \\
\hline & Scale of labor & 189 & 87 \\
\hline 1 & Lower than 50 employees & 19 & 9 \\
\hline 2 & From 50 to lower 150 employees & 2 & 1 \\
\hline 3 & From 150 to 500 employees & \multicolumn{2}{|l|}{} \\
\hline 4 & Over 500 employees & \multicolumn{2}{|l|}{} \\
\hline
\end{tabular}




\section{Results and Discussion}

\subsection{Test of the Reliability of Scale}

One of the popular methods for testing the reliability of a scale is to calculate the Cronbach's Alpha coefficient. Cronbach's Alpha coefficient will be run separately for each independent factor, thereby measuring the consistency among the variables of the same factor because the higher the consistency of observed variables, the higher the reliability of the scale. In this study, each factor, when being tested, must have Cronbach's Alpha score of 0.6 and over to be considered acceptable. If the factor's Cronbach's Alpha score reaches between 0.7 and 0.8 , it can be used and if it ranges from 0.8 to 1 , the reliability is high (Hair et al., 1998).

Meanwhile, the item-total correlation coefficient of each variable must reach 0.3 and over to be included in the next analysis. The variables, the coefficient of which is less than 0.3 , will be considered as non-informative variable and excluded before the factor analysis. Software SPSS.22 was used to support the analysis of the data collected after exclusion. The authors excluded two variables CA4 and AT5 due to their Cronbach's Alpha coefficients $<0.3$ (Hair et al., 1998). Among 27 variables of the remaining model, 21 independent variables and six dependent variables are included in the EFA model.

\subsection{Analysis of Exploratory Factor}

Principal Axis Factoring was used with Promax rotation (Anderson \& Gerbing, 1988) and factor loading coefficients $\geq 0.5$ (Hair et al., 1998) to incorporate remaining variables into Exploratory Factor Analysis (EFA) model for the purposes of scale validation. We have the resultant KMO coefficient $=0.855>0.5$; Bartlett's Test statistics are 3690.370 with significance level of $0.000<0.05$; Cumulative of Variance is $73.956 \%(>50 \%)$. This proves that the analytical data is perfectly relevant. Thus, all factor loading coefficients are greater than 0.5 ; explained variance is greater than $50 \%$, the remaining 27 observed variables are grouped exactly as the original scale.

After EFA exploratory analysis, it can be seen that the model has no difference from the research model, only some observed variables are unreliable so they are excluded from the study variable. There is no new factor group as follows (see Table 2):

\subsection{Analysis of Confirmatory Factor}

The EFA results show that there are seven key concepts in the research model. To measure the model's suitability with market information, we use Chi-square (CMIN), which is adjusted by degrees of freedom (CMIN/df), CFI,
GFI, TLI and RMSEA indices. The model is considered to be suitable with the market data when it receives TLI, CFI $\geq 0.9$; GFI $\geq 0.8$ (Bentler \& Bonelt, 1980), CMIN/df $\leq 3$ (Carmines \& McIver, 1981) RMSEA $\leq 0.08$ (Steiger, 1990). It is shown in the CFA results of the research model that it is suitable (Table 2). P-value results of the observed variables representing the factors all have the value sig. $=0.000$ so the observed variables are affirmatively considered to have good representation for the Confirmatory Factor Analysis (CFA) model factor. The correlation coefficient of each pair of concepts is different from 1 in the reliability of $95 \%$ $(\mathrm{P}$-Value value $=0.000)$ so the concepts achieve discriminant value. The weights (normalized) all are more than 0.5 and weights (non-normalized) are statistically significant (sig. $<0.000$ ) so the concepts achieve convergence value. This measurement model is compatible with market data and there is no correlation among measurement errors so it achieves uniqueness.

The result of CFA is presented in Table 2; on this CFA model, we observe that: Chisquare $/ \mathrm{df}=1.906<3$ (Carmines $\&$ McIver, 1981), CFI $=0.922>0.9 ;$ TLI $=0.910>0.9$ (Bentler \& Bonelt, 1980); GFI $=0.844>0.8$ và RMSEA= $0.065<0,8$ (Steiger, 1990). The weights of each observed variable are greater than 0.5 , so it is possible to see the model of convergence value. We obtain that the correlation coefficients are less than 1, testing covariance and correlation between pairs of variables are statistically significant (values of $\mathrm{p}<0.05$ ). This implies that it is possible to see the factors in the model gain discriminatory value.

\subsection{Test of Reliability after Exploratory Factor Analysis}

The result indicates that the Cronbach's Alpha coefficient of each factor obtains a value of more than 0.7 (i.e. in more precisely, the result of Cronbach's Alpha reliability of: RE: 0.920; TA: 0.903; CA: 0.845; AT: 0.849; EM: 0.880; SAT: 0.853; LOY: 0.698) and the item-total correlation coefficient is more than 0.3 , therefore, the scales all are reliable. We also obtain that, the combined reliability (CR) and Average Variance Extracted (AVE) of each factor has values greater than 0.5, which implies that the model is reliable (see Table 3).

\subsection{Structural Equation Modeling (SEM)}

The research uses linear SEM structure model to evaluate the suitability of the research model and test the relationships in the model. SEM obtain that, degrees of freedom $\mathrm{df}=308$, Chi-square $=580,656$ with the value of $p=0.000<0.05$, Chisquare $/ \mathrm{df}=1,885<3, \mathrm{CFI}=0.922>0.9, \mathrm{TLI}=0.912>0.9$; $\mathrm{GFI}=0.843>0.8$; RMSEA $=0.064<0.8$, it implies that, the model is suitable for data. 
Table 2: Analysis result of the exploratory factor

\begin{tabular}{|c|c|c|c|c|c|c|c|}
\hline \multicolumn{8}{|l|}{ Pattern Matrix ${ }^{a}$} \\
\hline & \multicolumn{7}{|c|}{ Factor } \\
\hline & 1 & 2 & 3 & 4 & 5 & 6 & 7 \\
\hline RE2 & .959 & & & & & & \\
\hline RE3 & .855 & & & & & & \\
\hline RE4 & .801 & & & & & & \\
\hline RE5 & .762 & & & & & & \\
\hline RE1 & .733 & & & & & & \\
\hline EM2 & & .890 & & & & & \\
\hline EM4 & & .796 & & & & & \\
\hline EM3 & & .796 & & & & & \\
\hline EM1 & & .747 & & & & & \\
\hline TA2 & & & .861 & & & & \\
\hline TA1 & & & .835 & & & & \\
\hline TA3 & & & .826 & & & & \\
\hline TA4 & & & .762 & & & & \\
\hline AT2 & & & & .879 & & & \\
\hline AT4 & & & & .823 & & & \\
\hline AT3 & & & & .709 & & & \\
\hline AT1 & & & & .614 & & & \\
\hline CA3 & & & & & .875 & & \\
\hline CA1 & & & & & .795 & & \\
\hline CA5 & & & & & .686 & & \\
\hline CA2 & & & & & .665 & & \\
\hline SAT2 & & & & & & .828 & \\
\hline SAT3 & & & & & & .725 & \\
\hline SAT1 & & & & & & .675 & \\
\hline LOY1 & & & & & & & .762 \\
\hline LOY3 & & & & & & & .642 \\
\hline LOY2 & & & & & & & .584 \\
\hline \multicolumn{8}{|l|}{ KMO: 0,855 } \\
\hline$\%$ of Variance & 32.880 & 9.038 & 8.571 & 7.573 & 6.529 & 5.263 & 4.102 \\
\hline Cumulative \% & 32.880 & 41.918 & 50.489 & 58.062 & 64.591 & 69.854 & 73.956 \\
\hline
\end{tabular}

Table 3: Test results of reliability of the scale

\begin{tabular}{|l|c|c|c|c|c|}
\hline Factor & $\begin{array}{c}\text { Number of } \\
\text { observed } \\
\text { variables }\end{array}$ & $\begin{array}{c}\text { Cronbach's Alpha } \\
\text { reliability }\end{array}$ & $\begin{array}{c}\text { Combined } \\
\text { reliability (CR) }\end{array}$ & $\begin{array}{c}\text { Average Variance } \\
\text { Extracted } \\
\text { (AVE) }\end{array}$ & $\begin{array}{c}\text { Convergence and } \\
\text { discriminant values }\end{array}$ \\
\hline Reliability (RE) & 5 & 0.919 & 0.920 & 0.699 & Satisfactory \\
\hline Tangibles (TA) & 4 & 0.903 & 0.905 & 0.704 & Satisfactory \\
\hline Capacity of staffs (CA) & 4 & 0.845 & 0.848 & 0.586 & Satisfactory \\
\hline Attitude of staffs (AT) & 4 & 0.849 & 0.853 & 0.595 & Satisfactory \\
\hline Empathy (EM) & 4 & 0.880 & 0.883 & 0.655 & Satisfactory \\
\hline Satisfaction (SAT) & 3 & 0.853 & 0.857 & 0.667 & Satisfactory \\
\hline Loyalty (LOY) & 3 & 0.698 & 0.760 & 0.514 & Satisfactory \\
\hline
\end{tabular}


We observe the SEM regression results is $\mathrm{P}<5 \%$, which therefore confirms that all hypotheses are accepted, in other words, factors such as Reliability (RE); Tangibles (TA); Capacity of staffs (CA); Attitude of staffs (AT) and Empathy (EM) all have a positive impact on customer satisfaction. The result also indicates that the factor with the most effect is Reliability (with impact factor $\beta=0.291$ ); next is Capacity of staffs (with $\beta=0.239$ ); then, Tangibles (with $\beta=0.192$ ); Attitude of staffs (with $\beta=0.190$ ); and the least impacting factor is Empathy (with $\beta=0.161$ ); On the other hand, the research results also show that Satisfaction has a strong impact on Customer Loyalty, with the coefficient $\beta=0.420$.

\subsection{Assessment of the Effects by Constituent Factors on Costumer Loyalty}

In Customer Loyalty model for online public service at Social Security of Thanh Hoa province, it can be seen, beside the direct impact from Customer Satisfaction, that Customer Loyalty is also affected indirectly by five factors constituting service quality. To assess the impact of the components of service quality on customer loyalty, the author uses direct, indirect and aggregate impact factors to evaluate. The results show that, the largest indirect effect belongs to Reliability $(\beta=0.100)$; next is Capacity of staffs $(\beta=0.084)$; Tangibles $(\beta=0.065)$; Attitude of staffs $(\beta=0.061)$; and finally Empathy $(\beta=0.052)$.

\section{Recommendations}

\subsection{Strengthening the Reliability of Online Service System}

The results show that the reliability is the most powerful factor linked to consumer satisfaction and the loyalty of enterprises. In fact, the reliability of online service system has an important role in processing social security. This issue is linked to the precise document; no documents have been lost by using online service system; the procedures are transparent; and the website has no virus to affect to documents. In order to strengthen the reliability of the online service system, the Social Security of Thanh Hoa province should continue focusing on professionalizing the online public services system. Currently, Social Security of Thanh Hoa province offers 23 online public services at level 3 and 4, however, there is no professional groups yet in each department directly working on the service, receiving, and support enterprises in using online public service. A professional group should be established in each department (for instance, One-stop Office to receive and return administrative procedure results; Department of Revenue Management; Department for issuing Social Security - health insurance cards; Department of Health
Insurance Inspection) with professional proficiency and a high knowledge of information technology.

\subsection{Capacity Building for Staffs at Social Security}

According to the regression results, the Capacity of staffs has a strong impact toward the satisfaction and loyalty of enterprises, so, the building of capacity should focus on: (i) strengthening professional training: Social Security staffs must have professional skills related to the laws on social insurance, health insurance and unemployment insurance; if not, they will not have enough capacity to support, to guide units and to deal with situations linked to online service system. Therefore, professional training is one of the important aspects to improve capacity; (ii) organizing IT training: Each staff needs to be proficient in using information technology applications in the field of social security to support work and better serve the subjects. From that point of view, it is necessary to prioritize in training IT skills for staffs at Social Security; (iii) organizing in-depth specialized training and retraining courses on each subject: it is also important to train with specific subject for staffs directly linked to their fields of activity functions; (iv) having policy to encourage staffs to self-study in order to improve their capacity (professional skills, foreign language, and informatics skills).

\subsection{Build Responsiveness of Electronic Transactions System}

Set up and organize the process of supporting units so that the support work is uniformly and smoothly implemented in the social insurance agency. A working room should be arranged for staff assigned to support online public service delivery units in one place. This office must be located in a convenient place, fully equipped with devices such as computers connected to the Internet, fully installed with application software, support tools, etc. There is a need to develop a software system to record the required contents, the time of the request of the unit and the time of processing, supporting and supporting results of each officer. The implementation of this software will ensure monitoring of the implementation of supporting units in electronic transactions.

\subsection{Improving the Empathy of Social Security's Staffs}

According to the research results, factors of professional responsibility and empathy are prominent, underlying great decisions for the satisfaction of organizations and individuals. The empathy factor includes the following components: always take care of the requests of participants; process 
records flexibly and in a timely manner; instructors and supporters feel good about the requirements; no harassment, troubles when handling records. In order to increase employee's empathy for businesses, Social Security needs to equip staff with necessary skills; building an independent reception channel to record the information about the attitude and responsibility of staffs processing documents to conduct electronic transactions.

\section{Reference}

Anderson, J. C., \& Gerbing, D. W. (1988). Structural Equation Modeling in Practice: A Review and Recommended Two-Step Approach. Psychological Bulletin, 103(3), 411-423. https://doi. org/10.1037/0033-2909.103.3.411

Bentler, P. M., \& Bonett, D. G. (1980). Significance tests and goodness of fit in the analysis of covariance structures. Psychological Bulletin, 88(3), 588-606. https://doi. org/10.1037/0033-2909.88.3.588

Black, K. (2010). Business Staticstics: Contemporary Decision Making (6th ed.). Hoboken, NJ: John Wiley \& Sons.

Bollen, K. A. (1986). Sample size and Bentler and Bonett's nonnormed fit index. Psychometrika, 51(3), 375-377. https:// doi.org/10.1007/BF02294061

Carmines, E. G. \& McIver, J. P. (1981). Analyzing models with unobserved variables: Analysis of covariance structures. In: Bohmstedt, G.W. \& Borgatta, E. F. (ed.), Social measurement: Current issues (pp. 66-115). Beverly Hills, CA: Sage Publications.

Chen, C. (2008). Investigating structural relationship between service quality, perceived value, satisfaction, and behavioral intentions for air passengers: Evidence from Taiwan. Transportation Research, 42(4), 709-717. https://doi. org/10.1016/j.tra.2008.01.007

Cronin Jr, J. J., \& Taylor, S. A. (1992). Measuring service quality: a reexamination and extension. Journal of Marketing, 56(3), 55-68. DOI: $10.2307 / 1252296$

Decree No. 43/2011/ND-CP of the Government. (2011). Stipulating the provision of information and online public services on websites or web portal of state agencies, date issued: 13/6/2011. Ministry of Planning and Investment, Hanoi, Vietnam.

Decree No: 45/2020/NĐ-CP. (2020). Regarding the implementation of administrative procedures in the electronic environment, date issued: 08/04/2020. Ministry of Planning and Investment, Hanoi, Vietnam.

Fan, J., \& Yang, W. (2015). Study on e-government services quality: The integration of online and offline services. Journal of Industrial Engineering and Management, 8(3), 693-718. http://dx.doi.org/10.3926/jiem.1405

Giao, H. N. K. (2020). Customer Satisfaction at Tiki. vn E-Commerce Platform. Journal of Asian Finance, Economics, and Business, 7(4), 173-183. https://doi.org/10.13106/ jafeb.2020.vol7.no4.173

Gremler, D. D., \& Brown, S. W. (1996). Service Loyalty: Its Nature, Importance, and Implications. In: Edvardsson, B., Brown, S.W., Johnston, R. \& Scheuing, E.E. (eds.), Advancing Service Quality: A Global Perspective (pp. 171-180). Waco, TX: International Service Quality Association.

Gronroos, C. (1984). A Service Quality Model and Its Marketing Implication. European Journal of Marketing, 18(4), 36-44.

Hair, J. F., Black, W. C., Babin, B. J., Anderson, R. E., \& Tatham, R. L. (1998). Multivariate data analysis. Upper Saddle River, NJ: Prentice-Hall.

He, Y., \& Wang, J. (2019). A Panel Analysis on the Cross Border E-commerce Trade: Evidence from ASEAN Countries. Journal of Asian Finance, Economics and Business, 6(2), 95-104. https://doi.org/10.13106/jafeb.2019.vol6.no2.95

Kotler, P., \& Keller, K. L. (2007). A framework for marketing management. Upper Saddle River, NJ: Prentice-Hall.

Kussusanti, S., Tjiptoherijanto, P., Halim, R. E., \& Furinto, A. (2019). Informational Justice and Post-recovery Satisfaction in E-Commerce: The Role of Service Failure Severity on Behavioral Intentions. Journal of Asian Finance, Economics and Business, 6(1), 129-139. https://doi.org/10.13106/ jafeb.2019.vol6.no1.129

Lehtinen, U., \& Lehtinen, J. R. (1982). Service quality: a study of quality dimensions. Service Management Institute, 5, 25-32.

Ngo, H. L. T. (2016). The Assessment on People's Satisfaction towards Public Administrative Services at the People's Committee of Di An Town, Binh Duong Province (pp.24-39). Master's Thesis. Ho Chi Minh City, Vietnam: Hong Bang International University.

Nguyen, H. H. (2019). The Study on People's Satisfaction towards Public Services of Viet Nam: Evidence of Tra Vinh Provincial Center of Public Administrative Services. Journal of Asian Finance, Economics and Business, 6(2), 183-187. https://doi. org/10.13106/jafeb.2019.vol6.no2.183

Nguyen, T. M. (2014). The Study on People's Satisfaction towards Public Administrative Services at People's Committee of Dak Ha District, Kon Tum province (pp.3645). Master's Thesis. Danang, Vietnam: The University of Danang.

Parasuraman, A., Zeithaml, V. A., \& Berry, L. L. (1988). SERVQUAL: A multiple-item scale for measuring consumer perception of service quality. Journal of Retailing, 64(1), $12-40$.

Rhee, S. K., \& Rha, J. Y. (2009). Public service quality and customer satisfaction: exploring the attributes of service quality in the public sector. The Service Industries Journal, 29(11), 1491-1512. https://doi.org/10.1080/02642060902793441

Steiger, J. H. (1990). Structural model evaluation and modification: An interval estimation approach. Multivariate Behavioral 
Research, 25(2), 173-180. https://doi.org/10.1207/ s15327906mbr2502_4.

Van de Walle, S., \& Scott, Z. (2009). The role of public services in state-and nation building: Exploring lessons from European history for fragile states ( $\mathrm{pp}$. 1- 21). Birmingham, UK: Governance and Social Development Resource Centre.
Zeithaml, V. A., Berry, L. L., \& Parasuraman, A. (1996). The behavioral consequences of service quality. Journal of Marketing, 60(2), 31-46. DOI: 10.2307/1251929.

Zeithaml, V. A., Parasuraman, A., \& Malhotra, A. (2000). E-service quality: definition, dimensions and conceptual model. Working Paper. Cambridge, MA: Marketing Science Institute. 